УДК 005.21

DOI: https://doi.org/10.26642/jen-2019-4(90)-118-125

І.М. Тесленок, к.е.н., доц.

С.В. Широколобов, магістр

Національний університет «Запорізька політехніка»

\title{
Оцінка конкурентоспроможності машинобудівного підприємства
}

Однією із важливих характеристик машинобудівного підприємства в умовах сучасного розвитку міжнародних ринкових відносин є показник рівня конкурентоспроможності. В статті відображена одна із методик оцінки рівня конкурентоспроможності підприємств, а саме побудова багатокутника конкурентоспроможності, згідно з якою визначається внутрішній $i$ загальний рівні конкурентоздатності AT «Мотор Січ» та їх порівняння з двома основними конкурентами - «CFM Int.» та «General Electric».

Відповідно до алгоритму проведення оцінки, було виділено і приведено до числового значення основні конкурентні переваги організації за допомогою кваліфікованих експертів підприємства та приведено до узгодженості їх відповіді за використанням коефіцієнта конкордаиії.

3 метою наочного порівняння числових значень факторів аналізованих підприємств були побудовані багатокутники конкурентоспроможності, на основі яких проведено розрахунок рівнів внутрішньої та зовнішньої конкурентоздатності організацій. Отримані дані використано при подальшому співвідношенні рівня конкурентоспроможності АT «Мотор Січ» із зазначеними конкурентами $i$ виведенні їх y числове значення через показники відносної внутрішньої $і$ загальної конкурентоспроможності підпиємства.

Результати дослідження дозволяють вирізнити слабкі місия у конкурентному «озброєнні» AT «Мотор Січ» та в подальшому розробити ряд заходів для повної чи часткової мінімізачії вказаних слабких місиьь.

Запропонований методологічний підхід щцодо оцінки рівня конкурентоспроможності організації та отримані в результаті дослідження висновки можуть знайти своє подальше застосування при визначенні доцільності зміни системи управління конкурентоспроможністю AT «Мотор Січ» та при пошуку иляхів підвищення його конкурентоздатності.
Ключові слова:
конкурентоспроможність підприємства;
показники конкурентоспроможності; багатокутник конкурентоспроможності; машинобудівне підприємство.

Актуальність теми. Зростання конкуренції на внутрішніх і зовнішніх ринках, прискорення науковотехнічного розвитку в усіх сферах суспільного життя зумовлюють необхідність для суб'єктів господарювання швидкої адаптації до змінюваних умов, ефективних рішень у сфері управління виробництвом. Для будь-якого підприємства конкурентоспроможність є одним із основних факторів забезпечення його виживання в умовах нестабільності і подальшого ефективного розвитку. Для успішного функціонування машинобудівного підприємства на ринку необхідно регулярно здійснювати оцінку його конкурентоспроможності. Така оцінка дає можливість визначити сильні та слабкі сторони підприємства, виявити його приховані потенційні можливості i, відповідно до цього, максимально удосконалити його стратегію функціонування.

Аналіз останніх досліджень та публікації, на які спирається автор. Питання конкурентоспроможності машинобудівних підприємств було і залишається актуальним для науковців. Базові положення теорії конкурентоспроможності описані в наукових працях: М.Портера [1], І.Ансоффа [2], Ж.Ламбена [3], Р.Фатхутдінова [4]. Науковий та практичний інтерес у визначенні конкурентоспроможності промислових підприємств становлять результати, подані в роботах таких вітчизняних вчених як Л.Балабанова [5], М.Галелюк [6], І.Піддубний [7], Л.Піддубна [7], О.Швиданенко [8], В.Шинкаренко [9] та інших. Актуальність оцінювання рівня конкурентоспроможності не зменшується і для машинобудівної галузі, яка є однією з провідних в економіці України, а їі розвиток визначає рівень матеріально-технічної бази країни.

Метою статті є оцінка внутрішнього та загального рівня конкурентоспроможності машинобудівного підприємства і його основних конкурентів на основі факторів конкурентоспроможності та за допомогою багатокутника конкурентоспроможності.

Викладення основного матеріалу. Оцінка конкурентоспроможності машинобудівного підприємства є складним і багатофакторним завданням, яке зводиться до інтерпретації і оцінки системи показників, які характеризують різні сторони діяльності підприємства, що формують його конкурентоспроможність [10, с. 94]. Оцінка конкурентоспроможності відбувається на основі

(C) I.М. Тесленок, Є.В. Широколобов, 2019 
вимірювання факторів, які мають порівнюватися з відповідними факторами основних конкурентів або 3 визначеними нормативами.

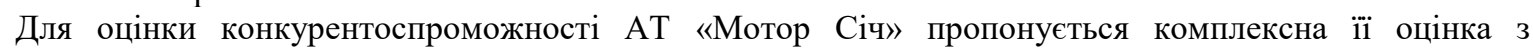
побудовою відповідної моделі.

Для оцінки конкуренції використовується узагальнений критерій внутрішнього суперництва підприємства та внутрішня відносна конкурентоспроможність організації. Внутрішні конкурентні переваги будуть оцінені п’ятьма експертами підприємства АТ «Мотор Січ», а саме: директором 3 маркетингу, фінансовим директором, директором 3 якості, заступником технічного директора $\mathrm{i}$ директором з корпоративних прав та інвестиційних проектів. Для виявлення узгодженості їх відповідей буде визначено коефіцієнт конкордації [11, с. 376].

Оцінка внутрішньої і загальної конкурентоспроможності проводилася для АТ «Мотор Січ», «СFМ Int.» (Франція/США) та «General Electric» (США), ринкові частки яких такі: АТ «Мотор Січ» - 4,5 \%, «CFM Int.»-34,8 \% та «General Electric»-18,3 \% [12, с. 302]. Оцінка проводитиметься за десятибальною шкалою.

На початку виокремлюються найбільш значущі аспекти внутрішньої конкурентної переваги: конкурентоспроможність продукції; фінансовий стан компанії; результативність маркетингової діяльності; рентабельність продажів; імідж підприємства; ефективність менеджменту.

Експертні оцінки факторів конкурентоспроможності АТ «Мотор Січ» та виділених конкурентів наведено у таблиці 1.

Оиінка факторів конкурентоспроможності АT «Мотор Січ»

Таблиця 1 та його основних конкурентів - «CFM Int.» ma «General Electric»

\begin{tabular}{|c|c|c|c|c|c|c|c|c|c|c|c|c|c|c|c|c|c|c|}
\hline \multirow[b]{2}{*}{ Фактор } & \multicolumn{6}{|c|}{ «Мотор Січ» } & \multicolumn{6}{|c|}{ CFM Int } & \multicolumn{6}{|c|}{ General Electric } \\
\hline & 1 & 2 & 3 & 4 & 5 & $\begin{array}{l}\text { сер. } \\
\text { бал }\end{array}$ & 1 & 2 & 3 & 4 & 5 & $\begin{array}{l}\text { сер. } \\
\text { бал }\end{array}$ & 1 & 2 & 3 & 4 & 5 & $\begin{array}{l}\text { сер. } \\
\text { бал }\end{array}$ \\
\hline $\begin{array}{l}\text { Конкуренто- } \\
\text { спроможність } \\
\text { продукції } \Phi 1 \\
\end{array}$ & 7 & 5 & 4 & 6 & 5 & 5,4 & 9 & 9 & 10 & 8 & 8 & 8,8 & 6 & 5 & 5 & 7 & 8 & 6,2 \\
\hline $\begin{array}{c}\text { Фінансовий } \\
\text { стан } \\
\text { підприємства } \\
\Phi 2 \\
\end{array}$ & 5 & 6 & 4 & 5 & 4 & 4,8 & 7 & 7 & 6 & 8 & 7 & 7 & 6 & 5 & 6 & 5 & 6 & 5,6 \\
\hline $\begin{array}{c}\text { Ефективність } \\
\text { маркетингово } \\
\text { і діяльності } \\
\text { Ф3 }\end{array}$ & 8 & 9 & 6 & 9 & 8 & 8 & 8 & 7 & 9 & 8 & 8 & 8 & 7 & 8 & 8 & 6 & 9 & 7,6 \\
\hline $\begin{array}{c}\text { Рентабельніст } \\
\text { ь продажів } \\
\text { Ф4 }\end{array}$ & 7 & 5 & 6 & 5 & 7 & 6 & 8 & 8 & 7 & 9 & 8 & 8 & 8 & 9 & 7 & 9 & 9 & 8,4 \\
\hline $\begin{array}{c}\text { Імідж } \\
\text { компанії Ф5 }\end{array}$ & 9 & 8 & 6 & 9 & 7 & 7,8 & 8 & 8 & 8 & 9 & 8 & 8,2 & 8 & 8 & 8 & 9 & 9 & 8,4 \\
\hline $\begin{array}{c}\text { Ефективність } \\
\text { менеджменту } \\
\text { Ф6 }\end{array}$ & 8 & 7 & 5 & 5 & 6 & 6,2 & 7 & 5 & 4 & 5 & 6 & 5,4 & 6 & 6 & 6 & 5 & 9 & 6,4 \\
\hline
\end{tabular}

Для оцінки узгодженості відповідей експертів розраховується коефіцієнт конкордації, дані для його розрахунку наведені у таблицях 2-4.

Відхилення від середнього рангу розраховується за формулою:

$$
\mathrm{d}_{\mathrm{j}}=\frac{\sum_{\mathrm{i}=1}^{\mathrm{n}} \mathrm{R}_{\mathrm{j}}}{\mathrm{n}}-\mathrm{F}_{\mathrm{j}},
$$

де $\mathrm{d}_{\mathrm{j}}-$ відхилення від середнього рангу;

$\mathrm{n}$ - кількість факторів;

$\mathrm{R}_{\mathrm{j}}$ - сума рангів, отриманих елементом $\mathrm{F}_{\mathrm{j}}$ від усіх експертів;

$\mathrm{F}_{\mathrm{j}}$ - аналізований фактор конкурентоспроможності підприємства. 
Дані для розрахунку коефіцієєта конкордації за експертною оичінкою АT «Мотор Січ»

\begin{tabular}{|c|c|c|c|c|c|c|c|c|}
\hline \multirow[b]{2}{*}{$\begin{array}{c}\text { Фактор } \\
\text { конкурентоспроможності } \\
\text { підприсмства }\end{array}$} & \multicolumn{5}{|c|}{ Оцінка експертів } & \multirow[b]{2}{*}{$\begin{array}{c}\text { Сума } \\
\text { рангів }\end{array}$} & \multirow{2}{*}{$\begin{array}{l}\text { Відхилення } \\
\text { від } \\
\text { середнього } \\
\text { рангу } \\
\end{array}$} & \multirow[b]{2}{*}{$\begin{array}{c}\text { Квадрат } \\
\text { відхилень }\end{array}$} \\
\hline & 1 & 2 & 3 & 4 & 5 & & & \\
\hline $\begin{array}{c}\text { Конкурентоспроможність } \\
\text { продукції Ф1 }\end{array}$ & 7 & 5 & 4 & 6 & 5 & 27 & 4,83 & 23,33 \\
\hline $\begin{array}{c}\text { Фінансовий стан підприємства } \\
\text { Ф2 }\end{array}$ & 5 & 6 & 4 & 5 & 4 & 24 & 7,83 & 61,31 \\
\hline $\begin{array}{l}\text { Ефективність маркетингової } \\
\text { діяльності Ф3 }\end{array}$ & 8 & 9 & 6 & 9 & 8 & 40 & $-8,17$ & 66,75 \\
\hline Рентабельність продажів Ф4 & 7 & 5 & 6 & 5 & 7 & 30 & 1,83 & 3,35 \\
\hline Імідж компанії Ф5 & 9 & 8 & 6 & 9 & 7 & 39 & $-7,17$ & 51,41 \\
\hline Ефективність менеджменту Ф6 & 8 & 7 & 5 & 5 & 6 & 31 & 0,83 & 0,69 \\
\hline Разом & & & & & & 191 & & 206,83 \\
\hline
\end{tabular}

Дані для розрахунку коефіųiєнта конкордащіï за експертною очінкою «CFM Int.»

\begin{tabular}{|c|c|c|c|c|c|c|c|c|}
\hline \multirow{2}{*}{$\begin{array}{c}\text { Фактор } \\
\text { конкурентоспроможності } \\
\text { підприємства }\end{array}$} & \multicolumn{5}{|c|}{ Оцінка експертів } & \multirow[b]{2}{*}{$\begin{array}{c}\text { Сума } \\
\text { рангів }\end{array}$} & \multirow{2}{*}{$\begin{array}{l}\text { Відхилення } \\
\text { від } \\
\text { середнього } \\
\text { рангу }\end{array}$} & \multirow[b]{2}{*}{$\begin{array}{c}\text { Квадрат } \\
\text { відхилень }\end{array}$} \\
\hline & 1 & 2 & 3 & 4 & 5 & & & \\
\hline $\begin{array}{c}\text { Конкурентоспроможність } \\
\text { продукції Ф1 }\end{array}$ & 9 & 9 & 10 & 8 & 8 & 44 & $-6,17$ & 38,07 \\
\hline $\begin{array}{c}\text { Фінансовий стан підприємства } \\
\text { Ф2 }\end{array}$ & 7 & 7 & 6 & 8 & 7 & 35 & 2,83 & 8,01 \\
\hline $\begin{array}{c}\text { Ефективність маркетингової } \\
\text { діяльності Ф3 }\end{array}$ & 8 & 7 & 9 & 8 & 8 & 40 & $-2,17$ & 4,71 \\
\hline Рентабельність продажів Ф4 & 8 & 8 & 7 & 9 & 8 & 40 & $-2,17$ & 4,71 \\
\hline Імідж компанії Ф5 & 8 & 8 & 8 & 9 & 8 & 41 & $-3,17$ & 10,05 \\
\hline Ефективність менеджменту Ф6 & 7 & 5 & 4 & 5 & 6 & 27 & 10,83 & 117,29 \\
\hline Разом & & & & & & 227 & & 182,83 \\
\hline
\end{tabular}

Дані для розрахунку коефіųiєнта конкордащиї за експертною очуінкою «General Electric»

Таблиияя 4

\begin{tabular}{|c|c|c|c|c|c|c|c|c|}
\hline \multirow{2}{*}{$\begin{array}{c}\text { Фактор } \\
\begin{array}{c}\text { конкурентоспроможності } \\
\text { підприємства }\end{array} \\
\end{array}$} & \multicolumn{5}{|c|}{ Оцінка експертів } & \multirow{2}{*}{$\begin{array}{c}\text { Сума } \\
\text { рангів }\end{array}$} & \multirow{2}{*}{$\begin{array}{c}\text { Відхилення } \\
\text { від середнього } \\
\text { рангу } \\
\end{array}$} & \multirow{2}{*}{$\begin{array}{c}\text { Квадрат } \\
\text { відхилень }\end{array}$} \\
\hline & 1 & 2 & 3 & 4 & 5 & & & \\
\hline $\begin{array}{l}\text { Конкурентоспроможність } \\
\text { продукції Ф1 }\end{array}$ & 6 & 5 & 5 & 7 & 8 & 31 & 4,50 & 20,25 \\
\hline $\begin{array}{l}\text { Фінансовий стан } \\
\text { підприємства Ф2 }\end{array}$ & 6 & 5 & 6 & 5 & 6 & 28 & 7,50 & 56,25 \\
\hline $\begin{array}{l}\text { Ефективність маркетингової } \\
\text { діяльності Ф3 }\end{array}$ & 7 & 8 & 8 & 6 & 9 & 38 & $-2,50$ & 6,25 \\
\hline Рентабельність продажів Ф4 & 8 & 9 & 7 & 9 & 9 & 42 & $-6,50$ & 42,25 \\
\hline Імідж компанії Ф5 & 8 & 8 & 8 & 9 & 9 & 42 & $-6,50$ & 42,25 \\
\hline $\begin{array}{c}\text { Ефективність менеджменту } \\
\text { Ф6 }\end{array}$ & 6 & 6 & 6 & 5 & 9 & 32 & 3,50 & 12,25 \\
\hline Разом & & & & & & 213 & & 179,5 \\
\hline
\end{tabular}

Коефіцієнт конкордації змінюється в діапазоні $0<\mathrm{W}<0$ - повна неузгодженість, 1 - повна одностайність.

Значення W від 0,2 до 0,4 свідчить про слабку узгодженість експертів, від 0,6 до 0,8 - про сильну узгодженість [13, с. 93]. 
Коефіцієнт конкордації визначається за формулою:

$$
\mathrm{W}=\frac{12 \times S}{n^{2} \times\left(m^{3}-m\right)},
$$

де $S$ - сума квадратів відхилень усіх оцінок рангів кожного об'єкта експертизи від середнього значення;

$n$ - число експертів;

$m$ - число об'єктів експертизи.

Під час оцінки факторів конкурентоспроможності АТ «Мотор Січ» (табл. 2) коефіцієнт конкордації W дорівнює:

$$
\mathrm{W}=\frac{12 \times 206,83}{25 \times(216-6)}=\frac{2481,96}{5250}=0,47 .
$$

Коефіцієнт конкордації для АТ «Мотор Січ» складає 0,47 і свідчить про достатній рівень узгодженості відповідей експертів.

Під час оцінки факторів конкурентоспроможності «СFM Int.» (табл. 3) коефіцієнт конкордації W дорівнює:

$$
\mathrm{W}=\frac{12 \times 182,83}{25 \times(216-6)}=\frac{2193,96}{5250}=0,42 .
$$

Коефіцієнт конкордації для «CFM Int.» складає 0,42 і свідчить про достатній рівень узгодженості відповідей експертів.

Під час оцінки факторів конкурентоспроможності «General Electric» (табл. 4) коефіцієнт конкордації W дорівнює:

$$
\mathrm{W}=\frac{12 \times 179,5}{25 \times(216-6)}=\frac{2154}{5250}=0,41 .
$$

Коефіцієнт конкордації для «General Electric» складає 0,41 і свідчить про достатній рівень узгодженості відповідей експертів.

На другому етапі розраховуються внутрішня конкурентоспроможність і загальна конкурентоспроможність зазначених компаній.

На початку будується багатокутник конкурентоспроможності внутрішніх конкурентних переваг аналізованих підприємств. Для його побудови необхідно привести до одиниці усі числові оцінки факторів, де як одиниця виступає ідеальна оцінка кожного чинника конкурентоспроможності. Наведені оцінки факторів конкурентоспроможності зазначені у таблиці 5.

Таблиия 5

Оијінка чинників конкурентоспроможності АТ «Мотор Січ» та його конкурентів за десятибальною шкалою і приведені до одинищі

\begin{tabular}{|c|c|c|c|c|c|c|}
\hline \multirow{2}{*}{ Фактори } & \multicolumn{2}{|c|}{ «Мотор Січ» } & \multicolumn{2}{|c|}{ «CFM Int.» } & \multicolumn{2}{|c|}{ «General Electric» } \\
\cline { 2 - 7 } & $\begin{array}{c}\text { Десятибальна } \\
\text { шкала }\end{array}$ & $\begin{array}{c}\text { Приведена } \\
\text { до одиниці }\end{array}$ & $\begin{array}{c}\text { Десятибальна } \\
\text { шкала }\end{array}$ & $\begin{array}{c}\text { Приведена } \\
\text { до одиниці }\end{array}$ & $\begin{array}{c}\text { Десятибальна } \\
\text { шкала }\end{array}$ & $\begin{array}{c}\text { Приведена } \\
\text { до одиниці }\end{array}$ \\
\hline $\begin{array}{c}\text { Конкуренто- } \\
\text { спроможність } \\
\text { продукції Ф1 }\end{array}$ & 5,4 & 0,54 & 8,8 & 0,88 & 6,2 & 0,62 \\
\hline $\begin{array}{c}\text { Фінансовий стан } \\
\text { підприємства Ф2 }\end{array}$ & 4,8 & 0,48 & 7 & 0,7 & 5,6 & 0,56 \\
\hline $\begin{array}{c}\text { Ефективність } \\
\text { маркетингової } \\
\text { діяльності Ф3 }\end{array}$ & 8 & 0,8 & 8 & 0,8 & 7,6 & 0,76 \\
\hline $\begin{array}{c}\text { Рентабельність } \\
\text { продажів Ф4 }\end{array}$ & 6 & 0,6 & 8 & 0,8 & 8,4 & 0,84 \\
\hline $\begin{array}{c}\text { Імідж компанії } \\
\text { Ф5 }\end{array}$ & 7,8 & 0,78 & 8,2 & 0,82 & 8,4 & 0,84 \\
\hline $\begin{array}{c}\text { Ефективність } \\
\text { менеджменту Ф6 }\end{array}$ & 6,2 & 0,62 & 5,4 & 0,54 & 6,4 & 0,64 \\
\hline
\end{tabular}

Багатокутники конкурентоспроможності внутрішніх конкурентних переваг для АТ «Мотор Січ», «CFM Int.» та «General Electric» зазначені на рисунках 1-3.

Обчислення об'єму піраміди, що буде проводитися пізніше, характеризує реальний результат оцінки конкурентоздатності підприємства, тобто величина цього параметра визначає кількісну оцінку конкурентоздатності. Основу піраміди - багатокутник - формують шість векторів-променів, що визначають внутрішню конкурентоздатність підприємства, величину якої можна розрахувати таким способом:

$$
\Pi_{\text {багаток }}=\frac{1}{2} \times \sin \alpha \times\left(\Phi_{1} \times \Phi_{2}+\Phi_{2} \times \Phi_{3}+\cdots+\Phi_{6} \times \Phi_{1}\right),
$$

де Пбагаток - площа основи піраміди (багатокутника конкурентоспроможності продукції); $\sin \alpha$ - кут між векторами в багатокутнику (основі), оскільки векторів у моделі шість, то кут буде дорівнювати $60^{0}$;

$\Phi_{1}, \ldots, \Phi_{6}-$ числова оцінка кожного фактора конкурентоспроможності, приведена до 1.

Кожний вектор у своєму граничному значенні являє собою радіус кола, що відповідає максимальному значенню (ідеальний варіант) оціночного показника, що дорівнює одиниці. 


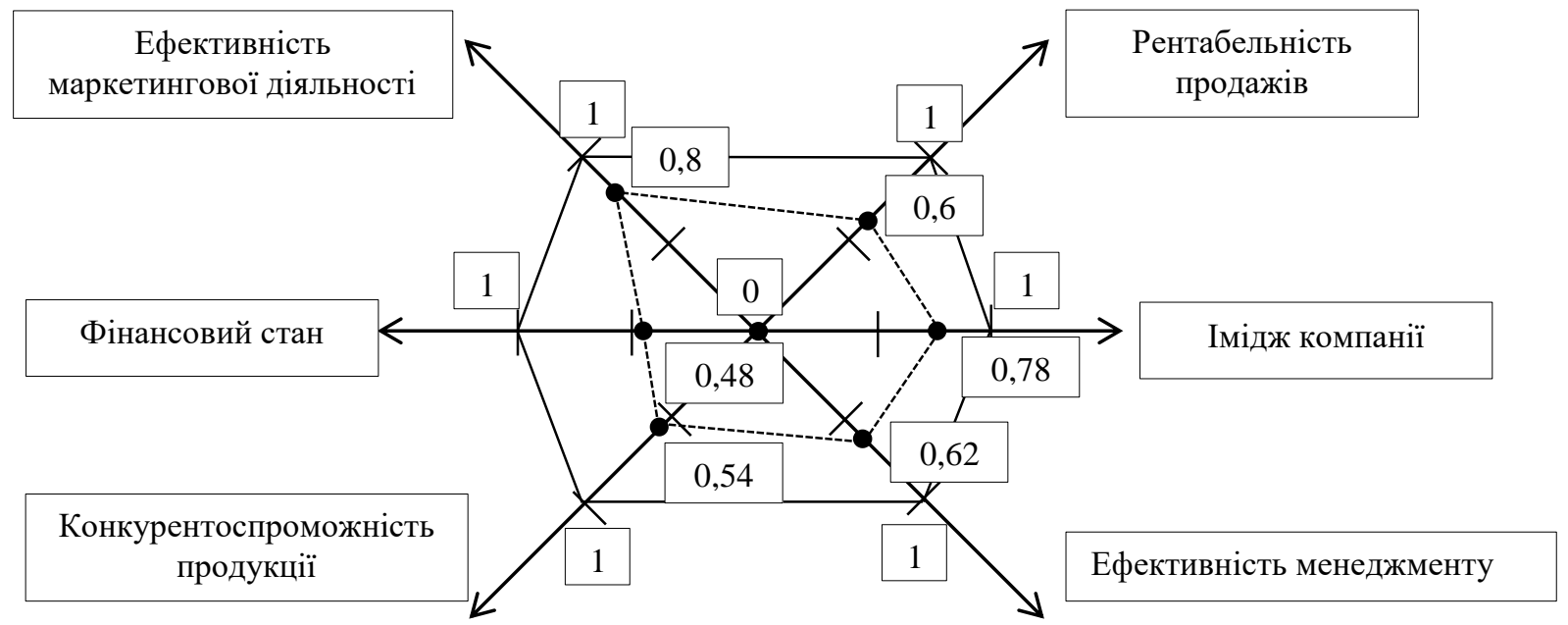

Рис. 1. Багатокутник конкурентоспроможності внутрішніх конкурентних переваг АТ «Мотор Січ»

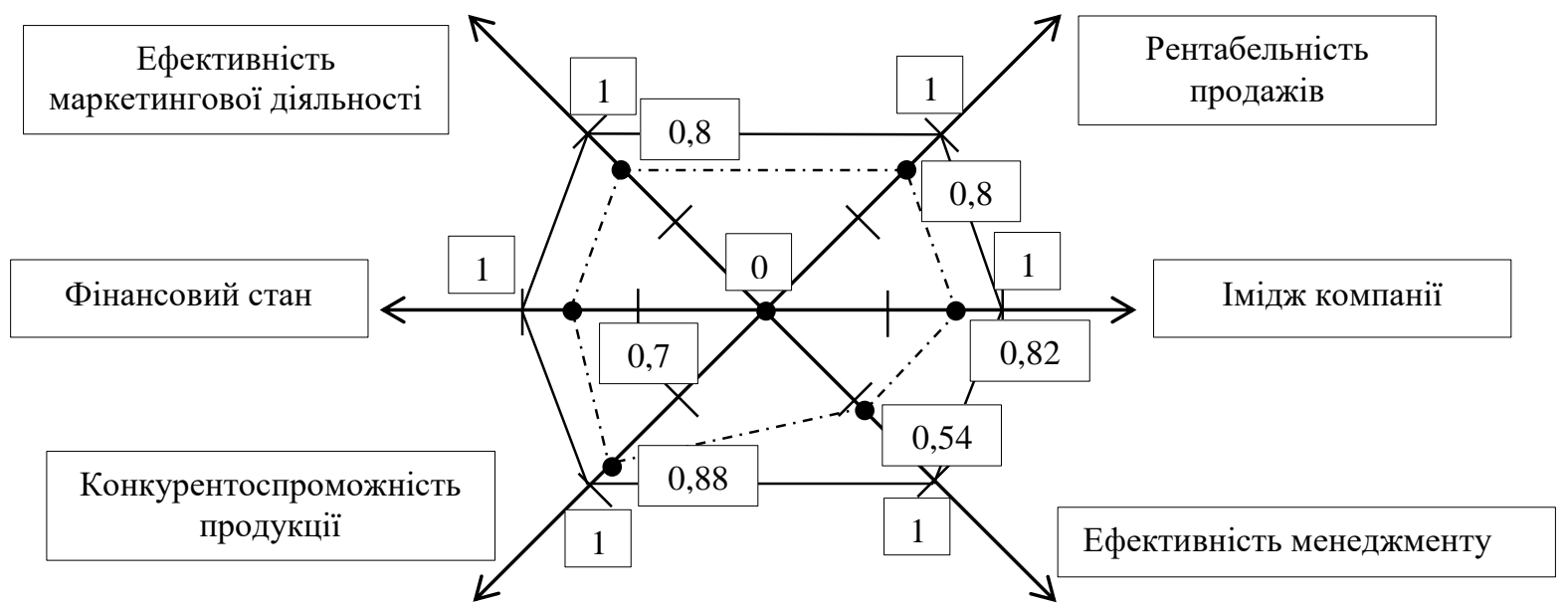

Рис. 2. Багатокутник конкурентоспроможності внутрішніх конкурентних переваг «CFM Int.»

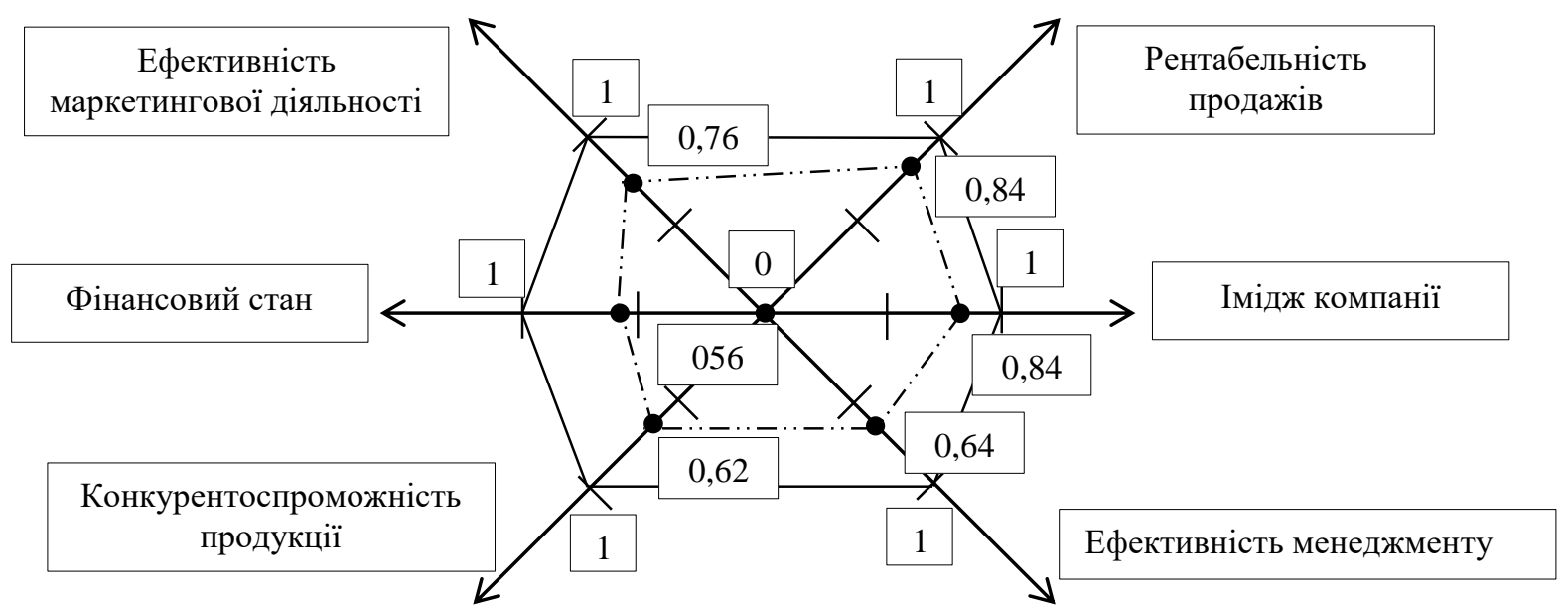

Pис. 3. Багатокутник конкурентоспроможності внутрішніх конкурентних переваг «General Electric» 
Внутрішня конкурентоспроможність АТ «Мотор Січ» за формулою 3 дорівнює:

Пбагаток $=\frac{1}{2} \times \sin 60 \times(0,54 \times 0,48+0,48 \times 0,8+0,8 \times 0,6+0,6 \times 0,78+0,78 \times 0,62+0,62 \times 0,54)=1,05$.

Внутрішня конкурентоспроможність ідеалу дорівнює:

$$
\text { Пбагаток }=\frac{1}{2} \times \sin 60 \times(1 \times 1+1 \times 1+1 \times 1+1 \times 1+1 \times 1+1 \times 1)=2,61 .
$$

Внутрішня конкурентоспроможність «СFM Int.» дорівнює:

$$
\text { Пбагаток }==\frac{1}{2} \times \sin 60 \times(0,88 \times 0,7+0,7 \times 0,8+0,8 \times 0,8+0,8 \times 0,82+0,82 \times 0,54+0,54 \times 0,88)=1,47 .
$$

Внутрішня конкурентоспроможність «General Electric» дорівнює:

$$
\text { Пбагаток }=\frac{1}{2} \times \sin 60 \times(0,62 \times 0,56+0,56 \times 0,76+0,76 \times 0,84+0,84 \times 0,84+0,84 \times 0,64+0,64 \times 0,62)=1,33 .
$$

Для оцінки загальної конкурентоспроможності компанії використовується ринкова частка підприємства, яка $є$ зовнішньою конкурентною перевагою і відображає дійсний стан компанії в конкурентному середовищі, частка ринку $(\mathrm{H})$ є висотою піраміди як оптимальний кількісний параметр.

Для розрахунку загальної конкурентоспроможності використовуємо формулу 4:

$$
\mathrm{E}_{\mathrm{K}}=\frac{1}{3} \times \Pi_{\text {багаток }} \times \mathrm{H},
$$

де $\mathrm{E}_{\kappa}$ - загальна оцінка конкурентоспроможності підприємства;

Пбагаток - площа основи піраміди (багатокутника конкурентоспроможності продукції);

Н - частка ринку компанії.

Загальна конкурентоспроможність АТ «Мотор Січ» за формулою 4 дорівнює:

$$
\mathrm{E}_{\mathrm{K}}=\frac{1}{3} \times 1,05 \times 0,045=0,016 .
$$

Загальна конкурентоспроможність «СFM Int.» дорівнює:

$$
\mathrm{E}_{\mathrm{K}}=\frac{1}{3} \times 1,47 \times 0,348=0,171 .
$$

Загальна конкурентоспроможність «General Electric» дорівнює:

$$
\mathrm{E}_{\mathrm{K}}=\frac{1}{3} \times 1,33 \times 0,183=0,081 .
$$

Загальна конкурентоспроможність ідеалу при ринковій частці, що не може перевищувати 65 \%, дорівнює:

$$
\mathrm{E}_{\mathrm{K}}=\frac{1}{3} \times 2,61 \times 0,65=0,565 .
$$

Відносна внутрішня конкурентоспроможність підприємства розраховується за формулою 5 :

$$
\mathrm{KC}_{\mathrm{B}}=\frac{\Pi_{\Pi}}{\Pi_{\text {баз }}} \times 100 \%,
$$

де $\Pi_{п}-$ внутрішня конкурентоспроможність аналізованого підприємства;

Пбаз - внутрішня конкурентоспроможність бази порівняння (конкурента або ідеалу).

Відносна внутрішня конкурентоспроможність АТ «Мотор Січ» до «СFM Int.» дорівнює 71,43 \%, до «General Electric» - 78,95 \%, до ідеалу - 40,23\%.

Відносна загальна конкурентоспроможність підприємства розраховується за формулою 6 :

$$
\mathrm{KC}_{\text {заг }}=\frac{\mathrm{E}_{\text {пा }}}{\mathrm{E}_{\text {баз }}} \times 100 \%,
$$

де $\mathrm{E}_{п}$ - загальна конкурентоспроможність аналізованого підприємства;

$\mathrm{E}_{\text {баз }}$ - загальна конкурентоспроможність бази порівняння (конкурента або ідеалу).

Відносна загальна конкурентоспроможність АТ «Мотор Січ» до «СFM Int.» дорівнює 9,36 \%, до «General Electric» - 19,75 \%, до ідеалу - 2,83\%.

Результат проведеного аналізу конкурентоспроможності АТ «Мотор Січ» та конкурентів представлено у таблиці 6.

Табличя 6

Показники конкурентоспроможності AT «Мотор Січ» та його конкурентів

\begin{tabular}{|c|c|c|c|c|}
\hline Рівні конкурентоспроможності & «Мотор Січ» & «CFM Int.» & $\begin{array}{c}\text { «General } \\
\text { Electric» }\end{array}$ & Ідеал \\
\hline Частка ринку & 0,045 & 0,348 & 0,183 & 0,65 \\
\hline Внутрішня конкурентоспроможність & 1,05 & 1,47 & 1,33 & 2,61 \\
\hline Загальна конкурентоспроможність & 0,016 & 0,171 & 0,081 & 0,565 \\
\hline $\begin{array}{c}\text { Відносна внутрішня } \\
\text { конкурентоспроможність } \\
\text { АТ «Мотор Січ», \% }\end{array}$ & & 71,43 & 78,95 & 40,23 \\
\hline $\begin{array}{c}\text { Відносна загальна конкурентоспроможність } \\
\text { АТ «Мотор Січ», \% }\end{array}$ & & 9,36 & 19,75 & 2,83 \\
\hline
\end{tabular}


Згідно з отриманими даними видно, що відносна внутрішня конкурентоспроможність АТ «Мотор Січ» нижче, ніж у основних конкурентів, так само як і загальна конкурентоспроможність. В основному на низький рівень конкурентоспроможності вплинули, на думку експертів, фінансовий стан підприємства та конкурентоспроможність продукції, що отримали найменші бали. Саме на ці слабкі сторони керівництву АТ «Мотор Січ» слід найперше звернути увагу при виборі нової конкурентної стратегії та при розробці нової моделі управління конкурентними перевагами підприємства й пошуку шляхів підвищення його конкурентоздатності.

Висновки та перспективи подальших досліджень. Виходячи з проведеного вище аналізу, можна сказати, що для успішного функціонування машинобудівного підприємства в умовах глибоких і швидких структурних змін міжнародного і національного ринку є обов'язковим проведення оцінки наявного рівня конкурентоспроможності. Проведення такого аналізу допоможе підприємству своєчасно виявити свої слабкі сторони, визначити приховані потенційні можливості, вловлювати тренди та тенденції, що існують на ринку і реагувати на їх вплив шляхом удосконалення стратегії функціонування.

У статті було проаналізовано внутрішню і загальну конкурентоспроможність АТ «Мотор Січ» та його основних конкурентів на міжнародному ринку - «СFM Int.» та «General Electric». Такі слабкі сторони, що й вплинули на низький рівень конкурентоспроможності АТ «Мотор Січ» відносно конкурентів, як фінансовий стан підприємства та конкурентоспроможність продукції потребують головної уваги керівного складу заводу та пошук шляхів їх підвищення.

Проведене дослідження буде корисним при подальшому визначенні доцільності зміни системи управління конкурентоспроможністю АТ «Мотор Січ» та формуванні нової моделі управління конкурентними перевагами підприємства.

\section{Список використаної літератури:}

1. Портер М. Конкурентное преимущество: как достичь высокого результата и обеспечить его устойчивость / М.Портер ; пер. англ. - М. : Альпина Бизнес, 2016. - 715 с.

2. Ансофф И. Новая корпоративная стратегия / И.Ансофф. - СПб. : Питер, 1999. - $416 \mathrm{c}$

3. Ламбен Ж.-Ж. Менеджмент, ориентированный на рынок / Ж.-Ж. Ламбен, Р. Чумпитас, И.Шулинг ; под ред. В.Б. Колчанова ; пер. англ. - 2-е изд. - СПб. : Питер, 2017. - 720 с.

4. Фатхутдінов Р.A. Управління конкурентоздатністю організації : підручник / Р.A. Фатхутдінов, Г.В. Осовська ; заг. ред. Г.В. Осовська. - К. : Кондор, 2012. -468 с.

5. Балабанова Л.В. Маркетинг підприємства : навч. посібник / Л.В. Балабанова, В.В. Холод, І.В. Балабанова. К. : Центр учбової літератури, 2012. - 612 с.

6. Галелюк M.M. Система управління конкурентоспроможністю машинобудування підприємства М.М. Галелюк // Вісник економічної науки України. - 2008. - № 2. - С. 15-21.

7. Піддубний I.O. Управління міжнародною конкурентоспроможністю підприємства / I.O. Піддубний, А.І. Піддубна. - Х. : ІНЖЕК, 2004. - 264 с.

8. Швиданенко $O$. Виробнича і споживча конкурентоспроможність країн: сутність, взаємозв'язок та система оцінювання / О.Швиданенко // Ринок цінних паперів України. Вісник Державної комісії з цінних паперів та фондового ринку. - 2012. - № 7. - С. 9-15.

9. Шинкаренко В.Г. Управление конкурентоспособностью предприятия / В.Г. Шинкаренко, А.С. Бондаренко. Х. : ХНАДУ, 2003. - $186 \mathrm{c}$.

10. Реутов В. Управление конкурентоспособностью : монография / В.Реутов, Н.Вельгош. - Симферополь : Таврия, 2005. - $200 \mathrm{c}$.

11. Трасковецька Л.М. Автоматизація математичних методів експертних оцінок / Л.М. Трасковецька, Л.В. Боровик, О.В. Боровик // Збірник наукових праць Національної академії Державної прикордонної служби України. Серія : Військові та технічні науки. - 2013. - № 2. - С. 373-384.

12. Гуржій Н.M. Аналіз конкурентоспроможності продукції ПАТ «Мотор Січ» на ринку авіадвигунів / Н.М. Гуржій, А.В. Маценко // Глобальні та національні проблеми економіки. - 2017. - № 20. - С. 301-304.

13. Гуржій Н.М. Оцінка конкурентоспроможності ПАТ «Мотор Січ» / Н.М. Гуржій, В.С. Мотика // Вісник Одеського національного університету. Серія : Економіка. - 2017. - Т. 22, Вип. 11. - С. 92-96.

\section{References:}

1. Porter, M. (2016), Konkurentnoe preimushhestvo: kak dostich' vysokogo rezul'tata i obespechit' ego ustojchivost', Al'pina Biznes, Moskva, 715 p.

2. Ansoff, I. (1999), Novaja korporativnaja strategija, Piter, Sankt Peterburg, 416 p.

3. Lamben, Zh.-Zh., Chumpitas, R. and Shuling, I. (2017), Menedzhment, orientirovannyj na rynok, in Kolchanova, V.B. (ed.), 2nd ed., Piter, Sankt Peterburg, 720 p.

4. Fathutdinov, R.A. and Osovs'ka, G.V. (2012), Upravlinnja konkurentozdatnistju organizacii', in Osovs'ka, G.V. (ed.), Kondor, Kyi'v, 468 p.

5. Balabanova, L.V., Holod, V.V. and Balabanova, I.V. (2012), Marketyng pidpryjemstva, Centr uchbovoi' literatury, Kyi'v, $612 \mathrm{p}$. 
6. Galeljuk, M.M. (2008), «Systema upravlinnja konkurentospromozhnistju mashynobuduvannja pidpryjemstva», Visnyk ekonomichnoi' nauky Ukrai'ny, No. 2, pp. 15-21.

7. Piddubnyj, I.O. and Piddubna, A.I. (2004), Upravlinnja mizhnarodnoju konkurentospromozhnistju pidpryjemstva, INZhEK, Harkiv, 264 p.

8. Shvydanenko, O. (2012), «Vyrobnycha i spozhyvcha konkurentospromozhnist' krai'n: sutnist', vzajemozv'jazok ta systema ocinjuvannja», Rynok cinnyh paperiv Ukrai'ny. Visnyk Derzhavnoi' komisii' z cinnyh paperiv ta fondovogo rynku, No. 7, pp. 9-15.

9. Shinkarenko, V.G. and Bondarenko, A.S. (2003), Upravlenie konkurentosposobnost'ju predprijatija, HNADU, Harkiv, $186 \mathrm{p}$.

10. Reutov, V. and Vel'gosh, N. (2005), Upravlenie konkurentosposobnost'ju, Tavrija, Simferopol', 200 p.

11. Traskovec'ka, L.M., Borovyk, L.V. and Borovyk, O.V. (2013), «Avtomatyzacija matematychnyh metodiv ekspertnyh ocinok», Zbirnyk naukovyh prac' Nacional'noi' akademii' Derzhavnoi' prykordonnoi' sluzhby Ukrai'ny, Ser. Vijs'kovi ta tehnichni nauky, No. 2, pp. 373-384.

12. Gurzhij, N.M. and Macenko, A.V. (2017), «Analiz konkurentospromozhnosti produkcii' PAT «Motor Sich» na rynku aviadvyguniv», Global'ni ta nacional'ni problemy ekonomiky, No. 20, pp. 301-304.

13. Gurzhij, N.M. and Motyka, V.S. (2017), «Ocinka konkurentospromozhnosti PAT «Motor Sich», Visnyk Odes'kogo nacional'nogo universytetu, Ser. Ekonomika, Vol. 22, Issue 11, pp. 92-96.

Тесленок Ірина Миколаївна - кандидат економічних наук, доцент Національного університету «Запорізька політехніка».

ORCID: 0000-0002-8495-5167.

Наукові інтереси:

- д дослідження впливу зовнішнього середовища на стратегічне управління підприємством.

E-mail: rishanya007@gmail.com.

Широколобов Свгеній Валерійович - магістр Національного університету «Запорізька політехніка». ORCID: 0000-0001-8037-0332.

Наукові інтереси:

- управління конкурентоспроможністю машинобудівного підприємства.

E-mail: kanakur1988@gmail.com.

Стаття надійшла до редакції 15.11.2019. 